\title{
Cash Conversion Cycle and Profitability of Textile Companies: Evidences from India
}

\author{
Ashvin R. Dave, Ashwin Parwani, Tejas Dave, Ashish Joshi
}

\begin{abstract}
Cash Conversion cycle is considered to be a useful measure to gauge the efficiency with which working capital of an enterprise is managed. In this research paper an attempt has been made to examine the relationship cash conversion cycle has with return on assets representing the measure of profitability and the extent to which it exerts its influence on the profitability. Size of the firm represented as log of sales and Financial Debt represented as total debt to total assets ratio are taken as control variables. We have considered only Indian textile companies listed on Indian stock exchanges. The study covers the period of nine years. The data was analysed using various statistical techniques including multiple regression analysis. F-test, auto correlation test using Durbin Watson Statistics and multi co linearity test using matrix of coefficients of correlation and variance inflation statistics were carried out to enhance the reliability of the results so obtained. The study revealed that both cash conversion cycle and size of the firm have strong and very significant negative association with profitability. The firms have to pay attention to ensure that length of cash conversion cycle and size of the firm remain optimum. The debt ratio was found to have insignificant negative association with profitability of the firm. The results of this research will provide insight to academicians and industrial experts for better decisions.
\end{abstract}

Keywords : Cash conversion cycle, return on assets, Textile. India,

JEL Classification: G 30, G31.

\section{INTRODUCTION}

Managing working capital, an integral part of financial management, encompasses twin aspects of deploying the resources and mobilising the resources as well. The Working capital of a business enterprise normally comprises of inventory, debtors, cash, marketable securities and creditors. Interestingly the business enterprises intend to convert inventory and debtors into cash as-fast-as they can. At the same time they do not intend to hold unnecessary cash as idle cash is a drain on profitability. Marketable securities provide a short term platform to park cash at least to generate some return. However,

Revised Manuscript Received on July 22, 2019.

* Correspondence Author

Dr.Ashvin R. Dave, Professor - Finance, SLS-PDPU, Gandhinagar-382007 Gujarat, INDIA

Mr.Ashwin Parwani, Visiting Scholar, SLS-PDPU, Gandhinagar-382007 Gujarat, INDIA

Dr Tejas Dave, Associate Professor, SLS-PDPU, Gandhinagar-382007 Gujarat, INDIA

Dr.Ashish Joshi, Associate Professor, SLS-PDPU, Gandhinagar-382007 Gujarat, INDIA to and fro transaction between cash and marketable securities assumes varying degree of frequency depending upon business needs. These components viz. inventory, debtors, marketable securities and cash refer to deployment of resources. Creditors are an important source of finance for working capital. A component of working capital that refers to either deployment of resources or mobilization of resources always carry a cost and also has an important role of facilitating day to day operations of the business. Therefore they have the potential to influence the profitability which every enterprise attempts to enhance in the modern complex and dynamic business world.

Cash Conversion Cycle (CCC) is a great measure to assess how well the business enterprise is organising its working capital. This measure indicates the no. of days starting from the date when the enterprise begins payments to suppliers and the date when the payments are received from the customers. It thus measures the time taken to convert cash into cash again from the time input inventory is purchased till the time output inventory is sold and cash is recovered from debtors. CCC has the potential to negatively affect profitability (M. Deloof - 2003 , Harrison Mwangi Muturi - 2015 and Zahra Chamaazii - 2017). At the same time it may positively impact the profitability of the enterprise (Ashok Kumar Panigrahi - 2013 and Saka, Rose Angahar, Paul Aondona, Ipevnor and Jennifer Mnena - 2017). Naturally proper management of CCC will help the enterprize in improving its profitability besides facilitating smooth functioning of business. Since profitability is an important corporate objective, every organization is obviously concerned with the factors affecting profitability. CCC deserves special attention. This research study pertains to examiningthe association of $\mathrm{CCC}$ and the extent influence it exerts over the profitability of the business enterprise in textile industry.The research community has widely visited various aspects of cash conversion cycle and observed mixed results. Some authors have noticed negative relationship between the CCC and profitability while others have observed the positive association between the two. There are few authors who observed that different components of $\mathrm{CCC}$ 
have different relationship with profitability of the firm. Their views are described in the lines to follow.Hyun-Han Shin and Luc Soenen [1] examined the association of net trade cycle with profitability of firms. They investigated 58,985 firms covering the period of 20 years spanning between the year 1975- and 1994. They found a strong negative relationship between the length of the firm's net-trade cycle and its profitability. They also observed that shorter net trade cycles are associated with higher risk-adjusted stock returns. M. Deloof [2] has analyzed the 1009 Belgian firms over the 1992-1996 period and found a significant negative relation between gross operating income and found that inventory, debtors and creditors were negatively related with gross operating income. He further noticed that this relationship was statistically relevant. In addition they observed that for better performance the time duration for collection of receivable should be kept as short as possible. Kesseven Padachi, M S Narasimhan, R Durbarry and C Howorth [3] examined the structural differences in working capital and the financing pattern of 58 small manufacturing firms, operating in five industry groups Food and Beverages ; Leather and Garments ; Paper Products and Printing; Prefabricated Metal Products ; and Wood Furniture for the period 1998-2003. The working capital position of the sample firms revealed that disproportionate increase in current asset in relation to sales resulted into a sharp decline in the working capital turnover. It was further observed that the short-term funds, particularly trade credit and other payables financed the major part of the working capital and the percentage of long-term funds used to finance the working capital had declined consistently during the same period. B.A Ranjith Appuhami [4] investigated the impact of firms' capital expenditure on their working capital management of listed companies in the Thailand Stock Exchange by using Net Liquidity Balance and Working Capital Requirement as a proxy for working capital measurement and developed multiple regression models They found that firms' capital expenditure has a significant impact on working capital management.Demirgunes. $\mathrm{K}$ and Samiloglu. F. [5] analysed how working capital management practices influenced profitability of manufacturing companies in Turkey for the period of $1998-2007$ by using multiple regression model and found that account receivables period, inventory period and leverage negatively affected firm's profitability; while growth in sales positively affected firm's profitability. Mian Sajid Nazir and Talat Afza [6] investigated the traditional relationship between working capital management policies and a firm's profitability by using the panel data set for the period 1998-2005 and found that investors prefer the stocks of those firms that adopt an aggressive approach to managing their short-term liabilities. Wesley S. Randall and M. Theodore Farris II [7] analyzed financial management techniques used to improve over all supply chain profitability and performance. They observed that by implementing a collaborative cash to cash management cycle with the usage of weighted average cost of capital the enterprise can increase the profitability. Huynh Phuong Dong and Jyh - Tay Su [8] analysed the association of cash conversion cycle with the profitability of the listed companies in Vietnam for the period of 2006-2008. They used the multiple regression model and found that there existed a strong negative relationship between profitability and the cash conversion cycle. This means that better value creation for the firm can take place if components of cash conversion cycle are kept at optimum level. Haitham Nobanee, Modar Abdullatif, Maryam Al Hajjar [9] investigated the association between the firm's cash conversion cycle and its profitability by using dynamic panel data analysis for Japanese firms for the period from 1990 to 2004 and noticed strong negative relation between the length of the firm's cash conversion cycle and its profitability except for consumer goods companies and services companies. Muneeb Ahmad Attari, Kashif Raza [10] studied association of the cash conversion cycle with the size and profitability of the firms in the four specific manufacturing sectors listed at Karachi Stock Exchange namely Automobile and Parts, Cement, Chemical, and Food Producers by using One-Way ANOVA and Pearson correlation techniques. They noticed that size of the firm and cash conversion cycle are negatively related. Also larger firms seem to manage their CCC days efficiently whereas their smaller counterparts happen to be struggling with their cash management issues. Sadia Majeed, Muhammad Abdul Majid Makki , Saba Saleem, Tariq Aziz [11] examined empirically the impact of Cash conversion cycle on the performance of Pakistani manufacturing firms using the sample of randomly selected 32 companies from three manufacturing sectors i.e. chemical, automobiles and construction material for the period of five years ranging from 2006 to 2010.They used the correlation and regression analysis to examine the relationship of $\mathrm{CCC}$ with performance of the firms and found that the average collection period of accounts receivables, inventory conversion period and Cash conversion cycle (CCC) have negative relationship with firm's performance. Faris Nasif Al-Shubiri Nassem Mohammad Aburumman [12] examined financial characteristics of the companies with reference to their cash conversion cycle. The study examined Jordanian 
companies belonging to different industrial sectors and listed on the Amman Stock Exchange covering the period 2005-2011. The results of the study indicated existence of statistically significant and positive relationship between cash conversion cycle and independent variables such as debt, market, productivity, liquidity and dividends. Dr. Ashok Kumar Panigrahi [13] investigated how profitability can be improved by proper management of cash conversion cycle in five cement manufacturing companies from 2001 to 2010. The regression model was used and it was noticed that Profitability and cash conversion cycle were positively related in a significant manner. Thus it is not necessary that cash conversion cycle always has negative association with the profitability. Harrison Mwangi Muturi [14] analyzed the effect of cash conversion cycle (CCC) on profitability of unlisted tea companies of Meru County in Kenya. The study used Census method to collect primary data from all the seven tea factories in the country. The correlation and regression analysis techniques were used for the study and it was observed that the CCC significantly and adversely affected the tea firms' profitability. Emmanuel Kojo Oseifuah and Agyapong Gyekye [15] investigated the the relationship between working capital management and profitability. They covered a sample of 75 non-financial firms listed on the Johannesburg Stock Exchange and used Panel data regression techniques. It was noticed that there existed a negative relationship between working capital management and corporate profitability. They also noticed that both inventory conversion period and accounts receivables conversion period had negative relationship with profitability. However, there existed a positive relationship between accounts payable deferral period and profitability. This study suggested that corporate managers can create value for shareholders by reducing the $\mathrm{CCC}$ to an extent that it enhances its profitability. Muhammad Qasim Maqbool and Umar Farooq [16] investigated the relationship across industries with respect to the length of CCC and working capital policies by using descriptive analysis, pearson correlation and the analysis of variance They concluded that in financial services sector there existed a negative but insignificant relationship between firms' size and CCC. Okpe Innocent Ikechukwu and Duru Anastesia Nwakaego [17] examined the effect of cash conversion cycle on the financial performance of building materials, chemical and paint manufacturing companies in Nigeria by using the techniques viz. generalized least square and multiple regression. They observed that inventory ratio and accounts receivable ratio had significant and positive effect on firms' profitability while accounts payable ratio and cash conversion cycle had positive but insignificant effect on firms' profitability. Zahra Chamaazii [18] examined the effects of cash conversion cycle on economic value added among companies listed on Tehran's stock exchange by using multivariate-regression method and observed that adverse and statistically significant relationship existed between companies' cash conversion cycle and their economic value added. Saka, Rose Angahar, Paul Aondona, Ipevnor, Jennifer Mnena [19] studied brewery firms quoted on the Nigerian Stock Exchange by using casual comparative research design and observed that financial performance and cash conversion cycle wre positively associated.The literature review described above clearly reveals that there are mixed results pertaining to the relationship of CCC with profitability of the firms. Some authors have found that CCC has significant negative association with profitability while others have observed significant positive association between the two. There are a few authors who have noticed that different components of the CCC have different relationship with profitability. This scenario accompanied by the fact that textile industry normally has high inventory and debtors, makes it imperative to further study the relationship of CCC with profitability and the extent to which it influences textile firms' fortunes.

\section{HYPOTHESES DEVELOPMENT}

On the basis of literature review described above the hypotheses developed are as under:

1. Ho: CCC does not influence profitabilty

$\mathrm{H} 1$ : CCC does influence profitabilty

2. Ho : Log of Sales does not influence profitability

H1: Log of Sales does influence profitabilty

3. Ho : Total Debt to Total Assets does not influence profitability

H1: Total Debt to Total Assets does influence profitabilty

\section{RESEARCH METHODOLOGY}

\section{Research Objective}

The research objectives of this research paper are :

1. To understand the association of cash Conversion Cycle, Firm's size and Financial Debt with profitability of the business enterprise.

2. To gauge the extent to which cash conversion cycle, Firm's size and Financial Debt influence the profitability.

\section{Research Techniques}

In this research study only textile sector companies listed on Indian stock exchanges have been covered. The variables considered are Return on Assets (ROA), Cash Conversion Cycle (CCC), Log of Sales and Financial Debt. Profitability of the firm is represented by Return on Assets and it is a dependent variable. $\log$ of sales representing firm's size, 
Cash Conversion Cycle and Financial Debt represented by Total Debt to Assets Ratio (TDTA) are the independent variables. Data for these variables were collected for a period of ten years to neutralize cyclical effects of the economy. The observations were analyzed using various statistical techniques. F test, Durbin Watson Test and Multi co linearity Test have been conducted to lend greater reliability to the results.

\section{RESULTS AND DISCUSSIONS}

The descriptive statistics placed at Table - 1 clearly point out that mean value of $\mathrm{CCC}$ is +82.439 days. The positive length of CCC of almost three months suggests that CCC is the element to be looked into carefully. It also indicates that firms' investment in inventory and debtors exceed the resources brought in by trade creditors. While examining the relationship between $\mathrm{CCC}$ and profitability it is clearly noticed that the standardized $\beta$ of CCC as stated in Table - 2 stands at -0.638 . This suggests inverse relationship with ROA. Its significance level of 0.000 makes it statistically very relevant. These statistical evidences clearly suggest that null hypothesis Ho be rejected and alternate hypothesis Ha be accepted. It means CCC exerts substantial influence on profitability (M. Deloof - 2003). In a similar way, the standardized $\beta$ (log of sales), as mentioned in Table- 2 , stands at -0.266 indicating negative association of $\log$ of sales with profitability. The value of $\beta$ (log of sales) is moderate but its significance level of 0.008 makes it a relevant variable influencing profitability. The statistical evidences therefore suggest that null hypothesis Ho be rejected and alternate hypothesis $\mathrm{Ha}$ be accepted. It means size of the firm has influence on profitability. In case of financial debt, as stated in Table- 2 the standardized $\beta$ (TDTA) is -0.035 suggesting negative relationship between Financial Debt and profitability. The value of $\beta$ (TDTA) is very low and its significance level of 0.729 renders it irrelevant as far as its influence on ROA is concerned. These evidences clearly advocate the acceptance of Ho and rejection of Ha leading us to believe that Financial Debt does not have effect on ROA. In order to lend considerable reliability to the results mentioned above F Test, Derbin Watson test and multi colinearity checks were carried out. The $\mathrm{F}$ test results given in Table- 3 shows $F=14.680$ at a significance level of 0.000 with $\mathrm{df}(3,68)$. This points out that all regression co-efficient will be non-zero. The output of auto correlation test i.e. Durbin Watson statistics placed at Table-3 indicates that $\mathrm{D}=1.675$. For $\mathrm{N}=72, \mathrm{dL}=1.58$ and $\mathrm{dU}=1.64$. As a result, $\mathrm{d}>\mathrm{dU}$ and $4-\mathrm{D}>\mathrm{dL}$. Thus there is no cause of concern from view point of either positive or negative auto correlation amongst the independent variables. The multi colinearity was checked using the matrix of co-efficient of correlation placed at Table -4 . This matrix indicates that none of the value exceeds \pm 0.700 . It means there is no cause of worry as far as multi co -linearity is concerned. This is further validated by VIF statistics given at Table - 2. Each of the VIF statistics is far away from 10 and each one centres around their mean. The resultant multiple regression equation is as under:

$\mathrm{ROA}=1.431-0.638(\mathrm{CCC})-0.266(\log$ of Sales $)-$ 0.035 (TDTA)
The adjusted $\mathrm{R}^{2}$ i.e. Coefficient of determination as shown in Table- 2 stands 0.366 This points out that $36.6 \%$ variations in Return on Assets can be explained by the above stated equation. For the remaining variations some other variables may have the role. The predictive value of the said equation shall be higher when the data set of the concerned sectors resembles to the parameters stated in descriptive statistics placed at Table-1.

\section{CONCLUSION AND FUTURE RESEARCH DIRECTIONS}

This research study clearly revealed that CCC has a strong negative significant association with the profitability of textile companies. ( Harrison Mwangi Muturi - 2015 and Zahra Chamaazii - 2017). The CCC clearly influences the profitability. The size of the firm also has negative significant relationship with profitability making it an important variable to be observed. The TDTA though has negative association with profitability it does not have any relevant influence. In nutshell the corporate managers have to pay more attention to CCC and size of the firm for better performance in terms of profitability. This research will have greater implications for both academics and practicing managers in the textile industry in India for policy making and control purposes. In this research study we have considered Indian textile companies registered at Bombay stock exchange and/or National stock exchange. Similar studies can be carried out for other sectors of the economy. A global study covering textile industry in developing as well as developed countries may as well be carried out to develop more insights into the behavior of CCC and its association with profitability. A study of the behavior of CCC and its influence on profitability may as well be considered for services sector in India and at global level as well.

Table 1: Descriptive Statistics

\begin{tabular}{|c|c|c|c|c|}
\hline 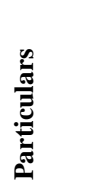 & $\Xi$ & 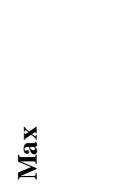 & 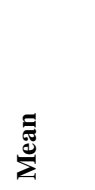 & 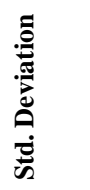 \\
\hline ROA & -0.169 & 3.955 & 0.0760 & 0.484 \\
\hline $\mathrm{CCC}$ & -263.369 & 303.187 & 82.439 & 81.839 \\
\hline $\begin{array}{l}\text { Log of } \\
\text { Sales }\end{array}$ & 4.668 & 7.3811 & 5.874 & 0.756 \\
\hline DTA & 0.016 & 1.178 & 0.588 & 0.234 \\
\hline
\end{tabular}

Table 2: Regression Coefficients - ROA

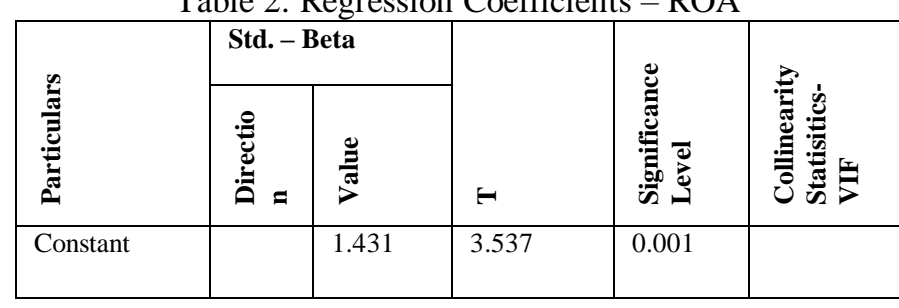




\begin{tabular}{|l|l|l|l|l|l|}
\hline CCC & - & 0.638 & -6.175 & 0.000 & 1.196 \\
\hline Log of Sales & - & 0.266 & -2.755 & 0.008 & 1.046 \\
\hline DTA & - & 0.035 & -0.348 & 0.729 & 1.150 \\
\hline
\end{tabular}

Independent Variables : CCC, Log of Sales, DTA

$\mathrm{N}=72 \mathrm{R}^{2}=0.366$ Dependent Variable : ROA

Table 3: Variance Analysis

\begin{tabular}{|c|c|c|c|c|c|c|}
\hline 氙 & 苛 & 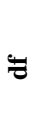 & 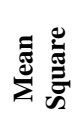 & 5 & $\dot{00}$ & 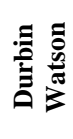 \\
\hline Regression & 6.543 & 3 & 2.18 & \multirow[t]{3}{*}{14.680} & \multirow[t]{3}{*}{0.0} & \multirow[t]{3}{*}{1.675} \\
\hline Residual & 10.103 & 68 & 0.14 & & & \\
\hline Total & 16.646 & 71 & & & & \\
\hline
\end{tabular}

Table 4:Matrix of Coefficients of correlations

\begin{tabular}{|c|c|c|c|c|}
\hline تُ & $\underset{ఝ}{\overleftarrow{\mid}}$ & U & 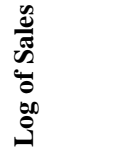 & 岕 \\
\hline ROA & 1.000 & -0.569 & -0.135 & +0.176 \\
\hline $\mathrm{CCC}$ & -0.569 & 1.000 & -0.210 & -0.361 \\
\hline $\begin{array}{l}\text { Log of } \\
\text { Sales }\end{array}$ & -0.135 & -0.210 & 1.000 & +0.072 \\
\hline DTA & +0.176 & -0.361 & +0.072 & 1.000 \\
\hline
\end{tabular}

\section{REFERENCES}

1. H.-H. Shin and L. Soenen, "Efficiency of Working Capital Management and Corporate Profitabilility,"Financial Practice and Education, vol. 8, pp. 37-45, 1998.

2. M. Deloof, "Does the working capital management affect the profitability of Belgium firms," Journalof business and Finance Accounting, vol. 30, no. 3,4, pp. 573 - 587, 2003.

3. K. Padachi, M. S. Narasimhan, R. Durbarry and C. Howorth, "An Analysis ofWorking Capital Structure and Financing Pattern of Mauritian Small Manufacturing Firms," The Icfai Journal of Applied Finance, vol. 14, no. 7, pp. $41-62,2008$.

4. B. RanjithAppuhami, "The Impact of Firms' Capital Expenditure on Working Capital Management: An Empirical Study across Industries in Thailand," International Management Review, vol. 4, no. 1, pp. 8-21, 2008.

5. K. Demirgunes and F. Samiloglu, "The effect of working capital management on Firm Profitability: Evidence from Turkey," The international Journal of Applied Economics and Finanace, vol. 2, no. 1, pp. 44-50, 2008.

6. M. S. Nazir and T. Afza, "Impact of Aggressive Working Capital Management Policy on Firms' Profitability," The IUP Journal of Applied Finance, vol. 15, no. 8, pp. 19-30, 2009.

7. W. S. Randall and M. T. Farris II, "Supply chain financing:using cash-to-cash variables to strengthen the supply chain," International Journal of Physical Distribution \& Logistics Management , pp. 669-689, 2009.

8. H. P. Dong and J.-t. Su, "The Relationship between Working Capital Management and Profitability: A Vietnam Case," International Research Journal of Finance and Economics, no. 49, pp. 59-67, 2010.

9. H. Nobanee, M. Abdullatif and M. AlHajjar, "Cash Conversion Cycle and Firm's Performance of Japanese Firms," Asian Review of Accounting, vol. 19, no. 2, pp. 147- 156, 2011.

10. M. A. Attari and K. Raza, "The Optimal Relationship of Cash Conversion Cycle with Firm Size and Profitability," International Journal of Academic Research in Business and Social Sciences, vol. 2, no. 4, pp. 189 - 203, April 2012.

11. S. Majeed, M. A. M. Makki, S. Saleem and T. Aziz, "The Relationship of Cash Conversion Cycle and Profitability of Firms: An Empirical Investigation of Pakistani Firms," Journal of Emerging Issues in
Economics, Finance and Banking (JEIEFB) An Online International Monthly Journal, vol. 1, no. 1, pp. 35 - 51, January 2013.

12. F. N. Al-Shubiri and N. M. Aburumman, "The relationship between cash conversion cycle and financial characteristics of industrial sectors: an empirical study," Investment Management and Financial Innovations, vol. 10, no. 4, pp. 95-102, 2013.

13. A. k. Panigrahi, "Cash conversion Cycle and Firms' Profitability - A Study of Cement Manufacturing Companies of India," International Journal of Current Research, vol. 5, no. 6, pp. 1484-1488, 2013.

14. H. MwangiMuturi, "Effects of cash conversion cycle on profitability of tea Factories in Meru county, Kenya," International Journal of Economics, Commerce and Management, vol. 3, no. 8, pp. $552-563$, 2015.

15. E. K. OSEIFUAH and A. GYEKYE, "Cash Conversion Cycle Theory and Corporate Profitability: Evidence from Non-Financial Firms Listed on the Johannesburg Stock Exchange," Journal for Accounting and Management, vol. 6, no. 3, pp. $37-51,2016$.

16. M. Q. Maqbool and U. Farooq, "Liquidity risk, performance and working capital relationship of cash conversion cycle: An empricial study of the firms in Pakistan," International Journal of Information Research and Review, vol. 3, no. 3, pp. 1946-1951, March 2016.

17. O. I. Ikechukwu and D. A. Nwakaego, "Cash Conversion Cycle Management on the Financial Performance of Building Materials/Chemical and Paint Manufacturing Companies in Nigeria," IOSR Journal Of Humanities And Social Science (IOSR-JHSS), vol. 21, no. 7, pp. 62-69, July 2016.

18. Z. Chamaazi, "The relation between cash conversion cycle and economic value added in companies listed on Tehran's stock exchange, Iran," European Journal of Economic and Financial Research, vol. 2, no. 2, pp. 91-112, 2017.

19. Saka, R. Angahar, P. Aondona, Ipevnor and J. Mnena, "Effect Of Inventory Retention And Cash Conversion Cycle On The Financia Performance Of Brewery FirmsQuoted On The Nigerian Stock Exchange," Imperial Journal of InterdisplinaryResearch(IJIR), vol. 3, no. 2, pp. 1040-1048, 2017 